Plasma Science and Applications (ICPSA 2013)

International Journal of Modern Physics: Conference Series

Vol. 32 (2014) 1460348 (8 pages)

(C) The Author

DOI: $10.1142 / \mathrm{S} 2010194514603482$

\title{
Soot oxidation in a corona plasma-catalytic reactor
}

\author{
H. Ranji-Burachaloo, S. Masoomi-Godarzi, A. A. Khodadadi*, M. Vesali-Naseh \\ and Y. Mortazavi \\ Catalysis and Nanostructured Materials Laboratory, School of Chemical Engineering, \\ College of Engineering, University of Tehran, Tehran, Iran \\ "khodadad@ut.ac.ir
}

Published 13 August 2014

\begin{abstract}
Oxidation of soot by corona plasma was investigated at conditions of exhaust gases from diesel engines, both in the absence and presence of $\mathrm{CoO}_{x}$ as a catalyst. The $\mathrm{CoO}_{x}$ catalyst nanoparticles were synthesized by a precipitation method. The BET surface area of the catalyst was $50 \mathrm{~m}^{2} / \mathrm{g}$, corresponding to $23 \mathrm{~nm}$ particles. An aluminum grid was sequentially dip-coated for several times by suspensions of the soot in toluene and/or fine catalyst powder in DI water. The grid was used as the plate of a pin-to-plate corona reactor. Air at $180{ }^{\circ} \mathrm{C}$ was passed through the corona reactor to oxidize the soot, oxidation products of which were analyzed by both gas chromatograph and FTIR with a gas cell. Soot oxidation rate linearly increased with an increase of input energy. When the soot was deposited on a layer of the $\mathrm{CoO}_{x}$ catalyst, the soot oxidation rate increased up to 2 times. The only product of the plasma (catalytic) oxidation of soot was $\mathrm{CO}_{2}$ determined by FTIR. $\mathrm{O}$ produced in the plasma discharge oxidized the soot and the active surface oxygen enhanced its rate.
\end{abstract}

Keywords: Corona plasma; Catalyst; Soot oxidation.

\section{Introduction}

Gasoline and diesel engines play important roles in urban air pollution. They emit a large amount of pollutants, including particulate matter (PM), carbon monoxide (CO) and nitrogen monoxide (NO). Particulate matters have negative effects on human health such as respiratory and mutagenic diseases like lung and bladder cancer. ${ }^{1}$ The PM in the raw exhaust gas primarily consists of soot which is a complex material. Few studies on soot suppression have been published. The conventional methods are dust collection using a filter and soot oxidation by combustion. However, they have a disadvantage of lowering the efficiency of soot suppression. ${ }^{2}$ As a result, Non-thermal plasma (NTP) processing has been attracted a lot of attention as the effective method to remove soot at low temperatures. It consists of free electrons as well as highly excited reactive radicals and ions.

This is an Open Access article published by World Scientific Publishing Company. It is distributed under the terms of the Creative Commons Attribution 3.0 (CC-BY) License. Further distribution of this work is permitted, provided the original work is properly cited. 
It has been reported that catalysts increase the soot removal efficiency. It has been found that transition metal oxides have catalytic activities to PM oxidation even more than the noble metal catalysts. Plasma discharge changes the catalytic activity of these transition metal oxides in a way that there are many active oxygen species such as $\mathrm{O}$ atoms, $\mathrm{OH}$ radicals, $\mathrm{O}_{3}$ and energized electrons and ions. ${ }^{3,4}$ The researchers have demonstrated the catalysts that promote soot oxidation in presence of $\mathrm{NO}_{2}$ or $\mathrm{O}_{3}$ which are produced by plasma discharges. However, few studies have been published on the PM catalytic oxidation under plasma discharge conditions. ${ }^{5}$

The aim of this work is to remove soot from diesel engine exhaust gases using a nonthermal plasma combined with a catalyst. We investigated the effect of input energy and catalyst and distribution of products.

\section{Experimental}

\subsection{Experimental set-up}

Figure 1 shows the experimental set up. It consisted of a pin-to-plate batch plasma catalytic reactor, a DC power supply $(30 \mathrm{kV} / 20 \mathrm{~mA})$, a resistance box and analytical instrumentation. The discharge voltage and current were measured with a voltage probe and a current probe, respectively. A gas mixture of $\mathrm{O}_{2}(10 \%)$ and $\mathrm{N}_{2}(90 \%)$ was fed into the reactor at a flow rate of $350 \mathrm{~mL} / \mathrm{min}$.

The reactor consisted of a pre heater and a batch-type corona reactor. The pre heater increased the temperature of input gas to $180^{\circ} \mathrm{C}$ (temperature of exhaust gas from diesel engines). The pin-to-plate corona reactor consisted of an aluminum grid as a plate and a platinum wire as a pin. The catalyst and soot were deposited on the plate layer by layer. The corona reactor has an inner diameter of $7 \mathrm{~mm}$ and an effective length of $1 \mathrm{~cm}$.

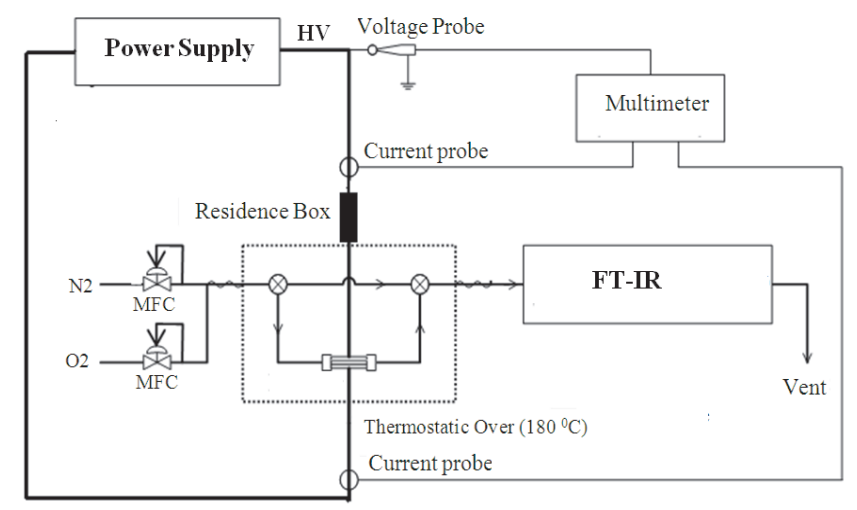

Fig. 1. Experimental plasma-catalysis set-up for soot oxidation. 


\subsection{Experimental analysis}

FTIR spectroscopy was used for determining the concentration of $\mathrm{CO}_{2}$ in the outlet gas stream, using a gas cell. The generation rates of $\mathrm{CO}_{2}\left(\mathrm{r}_{\mathrm{CO} 2}\right)$, soot oxidation rate $(\mathrm{r})$ and input energy (W) were calculated as follows ${ }^{6}$ :

$$
r_{\mathrm{CO}_{2}}=\mathrm{F} \times \mathrm{C}_{\mathrm{CO}_{2}}
$$

where $F$ is the total gas flow rate into the FTIR analysis cell $(350(\mathrm{~mL} / \mathrm{min}))$ and $C_{\mathrm{CO} 2}$ is the concentration of $\mathrm{CO}_{2}$,

$$
r=\frac{M_{(c)}}{R T} r_{\mathrm{CO}_{2}}
$$

where $\mathrm{M}_{(\mathrm{c})}$ is the molecular weight of carbon [g/mol], $R$ is the gas constant [L. atm $/ \mathrm{K}$. $\mathrm{mol}]$ and $T$ is the temperature of FTIR analysis cell $[\mathrm{K}]$,

$$
W=V \times I
$$

where $V$ is the discharge voltage $[\mathrm{kV}]$ and $I$ is the discharge current $[\mathrm{mA}]$.

\subsection{Catalyst preparation}

The $\mathrm{CoO}_{x}$ was prepared by precipitation method. $250 \mathrm{ml}$ of $\mathrm{Co}\left(\mathrm{NO}_{3}\right)_{2} \cdot 6 \mathrm{H}_{2} \mathrm{O}(0.05 \mathrm{M})$ solution was prepared.An ammonia solution $(1 \mathrm{M})$ was added drop wise to the solution at room temperature under vigorous stirring to adjust the $\mathrm{pH}$ value to 9 . The mixture was kept under moderate stirring for $12 \mathrm{~h}$ at $\mathrm{pH}$ 9. The precipitates were isolated and washed thoroughly to neutrality by centrifugation and finally dried in oven at $80{ }^{\circ} \mathrm{C}$ for $12 \mathrm{~h}$. The catalyst was calcinated at $350{ }^{\circ} \mathrm{C}$ for $3 \mathrm{~h}^{7}$ The prepared catalyst $(10 \mathrm{mg})$ was dissolved in $1 \mathrm{ml}$ of deionized water. $0.5 \mathrm{ml}$ of dispersed solution was deposited on the aluminum grid surface and allowed to dry at $80{ }^{\circ} \mathrm{C}$ in oven. Then, $10 \mathrm{mg}$ of Soot was dissolved in $1 \mathrm{ml}$ of toluene. $0.8 \mathrm{ml}$ of prepared solution was deposited on the layer of catalyst.

\section{Results and Discussion}

\subsection{Catalyst characterization}

The specific surface area $\left(\mathrm{S}_{\mathrm{BET}}\right)$ of $\mathrm{CoO}_{\mathrm{x}}$ was measured with a BET (CHEMBET-3000, Quantachrome) using the single point BET surface area. Prior to measurement, the catalyst was subjected to a final purging while it was heated to $300{ }^{\circ} \mathrm{C}$ in flowing $\mathrm{N}_{2}$ for 2 hour. Then, the sample which was subjected to a flow of $15 \% \mathrm{He}$ in $\mathrm{N}_{2}$ was settled in a liquefied Nitrogen cell in order that Nitrogen was absorbed on its surface at the temperature of $196{ }^{\circ} \mathrm{C}$ and atmospheric pressure. Desorption process was performed in the atmospheric pressure and room temperature and output was monitored. Finally, the system was calibrated with the injection of certain volume of Nitrogen gas to determine the number of adsorbed Nitrogen moles at the surface. The number of adsorbed Nitrogen 
moles at the surface was calculated using the surface area of calibration and desorption curves and the specific surface area was calculated by the system assuming that Nitrogen molecules are spherical. The average particle diameter of $\mathrm{CoO}_{\mathrm{x}}$ was calculated from BET specific surface area as following equation:

$$
d_{B E T}=\frac{6}{S_{B E T} \times \text { Skeletal density }},
$$

where the skeletal density of $\mathrm{CoO}_{\mathrm{x}}$ was reported $5.18 \mathrm{~g} / \mathrm{cm}^{3}$.

The results show that $\mathrm{S}_{\mathrm{BET}}$ and $\mathrm{d}_{\mathrm{BET}}$ for $\mathrm{COO}_{\mathrm{x}}$ are $50 \mathrm{~m}^{2} / \mathrm{g}$ and $23 \mathrm{~nm}$, respectively. It indicates that the specific surface area of the catalyst is high, as compared to $1.35 \mathrm{~m}^{2} / \mathrm{g}$ reported by Yamamoto et $\mathrm{al}^{6}$ and $12 \mathrm{~m}^{2} / \mathrm{g}$ reported by Yucheng Du et al. ${ }^{8}$ This plays an important role in facilitating the oxidation process.

\subsection{Soot oxidation rate without catalyst}

Figure 2 shows the generation rates of $\mathrm{CO}_{2}$ at various times during the soot oxidation by plasma discharge using the corona reactor at input energy of $4.5 \mathrm{~W}$ without catalyst support. The plasma discharge began at the time of zero. During the first three minutes, the generation rates of the product increase rapidly because a respond time of approximately three minutes is required for the FTIR analysis. The generation rates of $\mathrm{CO}_{2}$ become steady at the level of $0.25 \mathrm{ml} / \mathrm{min}$ after three minutes until soot removed from the surface.

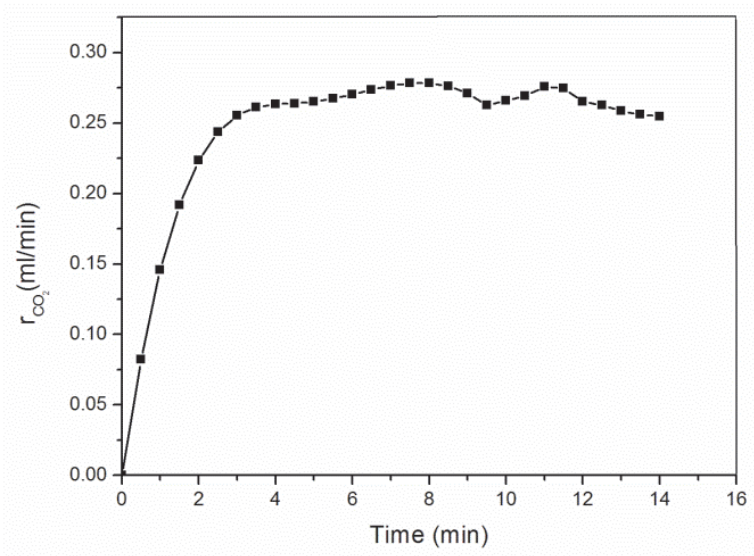

Fig. 2. Generation rate of $\mathrm{CO}_{2}$ versus time using a non catalytic-corona plasma reactor.

Figure 3 indicates the soot oxidation rates as a function of input energy. As shown in the Fig.2, the soot oxidation rates increase with an increase in input energy in the range of 2-4.5 W. It can be concluded that increasing the number of electrons, ions and radicals generated in plasma in higher voltage facilitate the oxidation process of soot. It finally reaches $1.8 \mathrm{~g} / \mathrm{kWh}$ at $4.5 \mathrm{~W}$ which is high in comparison to the reported values. ${ }^{9}$ 


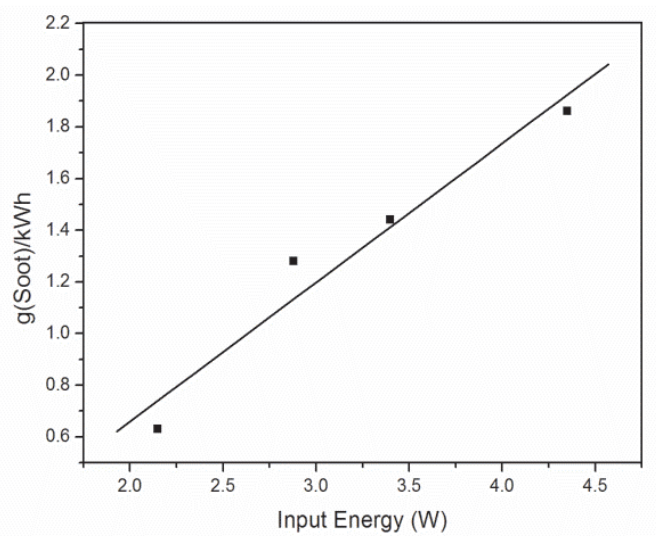

Fig. 3. Soot oxidation rate in a corona plasma reactor without catalyst as a function of input energy.

\subsection{Soot oxidation rate with catalyst}

Figure 4 shows the generation rates of $\mathrm{CO}_{2}$ at various times during the soot oxidation by plasma discharge using the corona reactor at input energy of $4.5 \mathrm{~W}$ with $5 \mathrm{mg} \mathrm{CoO}_{\mathrm{x}}$ as a catalyst. The generation rates of $\mathrm{CO}_{2}$ become steady after three minutes at a level of $0.45 \mathrm{ml} / \mathrm{min}$ which is higher than the corresponding value of the non catalytic reactor $(0.25 \mathrm{ml} / \mathrm{min})$. It indicates the effective role of catalyst in the oxidation of soot. This rate continues until soot removed from the surface.

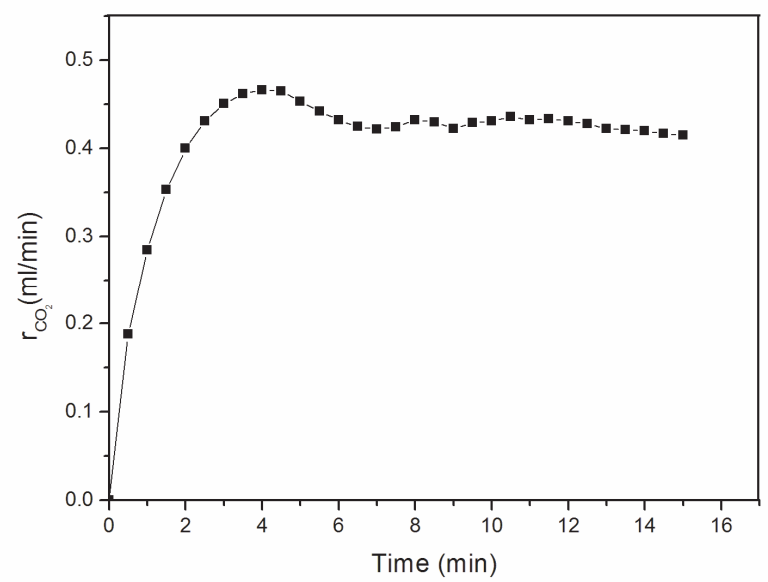

Fig. 4. Generation rate of $\mathrm{CO}_{2}$ using a corona plasma reactor with $\mathrm{CoOx}$ as catalyst.

Figure 5 compares the soot oxidation rates in a catalytic and non-catalytic corona discharge reactor as a function of input energy. As shown in the Fig.5, the soot oxidation rates increase with an increase in input energy in the range of 2-4.5 W for both catalytic and non-catalytic reactor. It finally reaches $3.5 \mathrm{~g} / \mathrm{kWh}$ at $4.5 \mathrm{~W}$ in catalytic reactor. As a 
result, the soot oxidation rates in the presence of $5 \mathrm{mg} \mathrm{CoO}_{\mathrm{x}}$ show an increase, as compared to the non-catalytic reactor $(1.8 \mathrm{~g} / \mathrm{kWh})$. This result indicates the role of $\mathrm{CoO}_{\mathrm{x}}$ NPs in increasing the soot oxidation rate. This soot oxidation efficiency is high in comparison with other plasma catalytic reactor. ${ }^{10}$

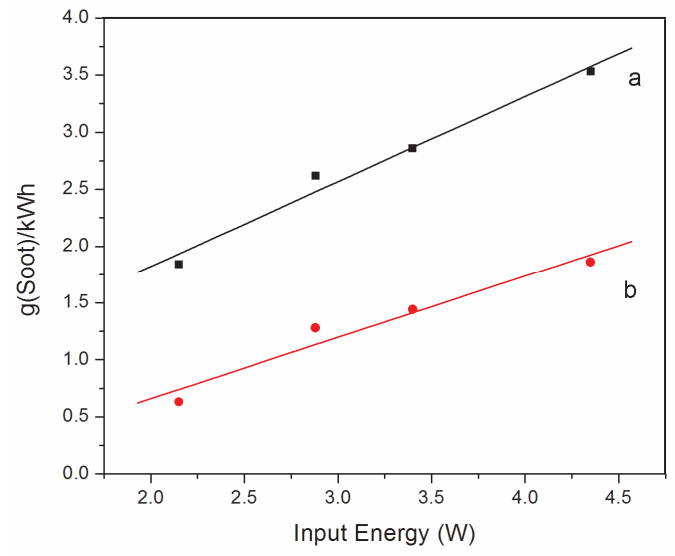

Fig. 5. Soot oxidation rate in a corona plasma reactor as a function of input energy a) with $\mathrm{CoO}_{\mathrm{x}}$ as catalyst and b) without catalyst.

The mechanism of catalytic soot oxidation has been reported by Mars and van Krevelen. $\mathrm{O}_{2}$ molecules are decomposed by plasma discharges to $\mathrm{O}$ atoms. Soot can be oxidized via gaseous $\mathrm{O}$ atoms and $\mathrm{O}_{2}$ to $\mathrm{CO}$ and $\mathrm{CO}_{2}\left(\mathrm{R}_{1}\right)$. Soot oxidation is promoted by $\mathrm{O}$ atoms that transport on the surface of catalysts $\left(\mathrm{R}_{2}\right){ }^{6}$. From the fact that the soot oxidation rate over $\mathrm{Co}_{2} \mathrm{O}_{3}$ is 1.8 times of that over aluminum surface (without catalyst), $55.5 \%$ of soot is removed via $\mathrm{R}_{1}$ and $44.5 \%$ of soot is removed via $\mathrm{R}_{2}$. As the $\mathrm{Co}_{2} \mathrm{O}_{3}$ has no catalytic effect on soot oxidation at $180{ }^{\circ} \mathrm{C}$ without plasma discharges ${ }^{11}$, the increase in soot oxidation rate with $\mathrm{Co}_{2} \mathrm{O}_{3}$ layer implied that $\mathrm{Co}_{2} \mathrm{O}_{3}$ layer on aluminum grid surface has synergy effect on promotion of soot oxidation under plasma discharge conditions. In addition, ozone which is produced in plasma discharge is decomposed in the vicinity of the catalyst leading to a decrease of the disposal of ozone to be catalytically decomposed on the catalyst.$^{12}$ Hence, the improvement of soot oxidation rate when adding a catalyst is related to its ability to dissociate ozone and $\mathrm{O}$ atoms that transport on its surface.

\subsection{Distribution of products in plasma non-catalytic reactor}

It has been concluded that non-thermal plasma does not usually allow the simultaneous achievement of both a high conversion and selectivity with respect to the desired reactions. In this work, we prepared the conditions in a way that the oxidation reaction produced only desired product. Figure 6 indicates the FTIR spectrum of outlet gas stream from plasma non-catalytic corona reactor for input energy of $4.5 \mathrm{~W}$. It shows that the 
product of the oxidation reaction is only $\mathrm{CO}_{2}$. There is no $\mathrm{NO}_{\mathrm{x}}$ or other by-products which are common in the products of other plasma reactors.

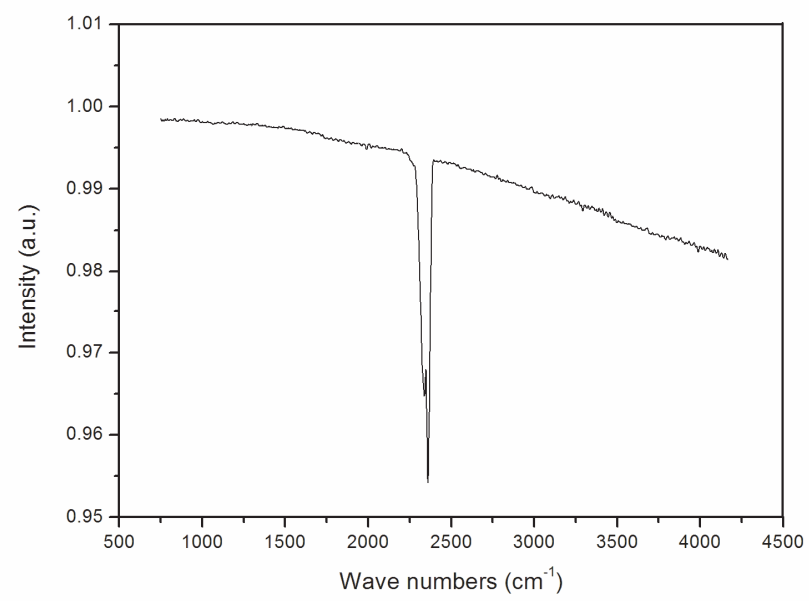

Fig. 5. FTIR spectrum of outlet gas stream from a non-catalytic corona reactor.

\section{Conclusion}

The soot oxidation of exhaust gas from diesel engine was investigated by non-thermal plasma using a batch-type corona reactor with pin-to-plate electrode configuration without and with $\mathrm{CoO}_{\mathrm{x}}$ catalyst. The soot oxidation rate increases with input energy. The soot oxidation rates are $3.5 \mathrm{~g} / \mathrm{kWh}$ and $1.8 \mathrm{~g} / \mathrm{kWh}$ at input energy of $4.5 \mathrm{~W}$ in catalytic and non-catalytic reactor, respectively. The improvement of soot oxidation rate in the presence of catalyst is related to its ability to dissociate ozone to $\mathrm{O}$ atoms and presence of $\mathrm{O}$ atoms that transport on its surface. $\mathrm{O}^{-}$atoms generated by plasma discharges may play an important role in promoting the re-oxidation of metal under plasma discharge conditions. Distribution of products in non-catalytic corona plasma shows that $\mathrm{CO}_{2}$ is the only product of oxidation reaction.

\section{References}

1. M. Moldovan, M.A. Palacios, M.M. Gomez, G. Morrison, S. Rauch, C. Mclcod, R. Ma, S. Caroli, A. Alimonti, F. Petrucci, B. Bocca, P. Schramel, M. Zischka, C. Pettersson, U. Wass, M. Luna, J.C. Saenz and J. Santamaria, Sci. Total Environ. 296, 199 (2002).

2. M. Saito, M. Sato and K. Sawada, J. Electrostatics 39, 305 (1997).

3. R. Dorai, K. Hassouni and M.J. Kushner, Appl. Catal. B 147, 904 (2014).

4. J. Grundmann, S. Müller and R.J. Zahn, Plasma Sources Sci. T. 12, 412 (2003).

5. Y. Dan, G. Dengshan, Y. Gang, S. Xianglin and G. Fan, J. Hazard. Mater. 127, 149 (2005).

6. S. Yamamoto, S. Yao, S. Kodama, C. Mine and Y. Fujioka, The Open Catalysis Journal 1, 11 (2008).

7. J. Karuppiah, R. Karvembu and Ch. Subrahmanyam, Chem. Eng. J. 180, 39 (2012). 
8. Y. Du, Q. Meng, J. Wang, J. Yan, H. Fan, Y. Liu and H. Dai, Microporous Mesoporous Mater. 162, 199 (2012).

9. S. Yao, M. Okumoto, T. Yashima, J. Shimogami, K. Madokoro and E. Suzuki, AIChE. 50, 715 (2004).

10. Y.S. Mok and Y.J. Huh, Plasma Chem. Plasma P. 25, 625 (2005).

11. P.G. Harrison, I.K. Ball, W. Daniell, P. Lukinskas, M. Céspedes, E.E. Miró and M.A. Ulla, Chem. Eng. J. 95, 47 (2003).

12. M.T. Nguyen Dinh, J.M. Giraudon, J.F. Lamonier, A. Vandenbroucke, N. De Geyter, C. Leys and R. Morent, Appl. Catal. B 147, 904 (2014). 